\section{Hvor stabilt er tenåringers evnenivå?}

\author{
En studie der tenåringer ble IQ-testet og MR-undersøkt med fire års \\ mellomrom tyder på at hjernen er mer plastisk enn hittil antatt.
}

Testes en person over tid, kan forskjellige resultater skyldes målefeil. Men målefeil blir mindre sannsynlig hvis variasjoner i IQ-skår samvarierer med endringer i hjernebarken, målt med strukturell og funksjonell MR. Spesielt plausible vil funnene være hvis endringene ses i barkområder der funksjon kan knyttes til typen IQ-test som benyttes: En person kunne for eksempel i løpet av noen år skåre bedre på en verbal IQ-test enn tidligere, og samtidig kunne det måles økt cortextetthet i venstre presentrale gyrus. Eller vedkommende skåret dårligere i en ikke-verbal test, og cortextettheten i fremre cerebellum var samtidig blitt redusert. Slike resultater ville tyde på at hjerneutviklingen i tiden mellom de to målingene var mer plastisk enn man hittil har trodd. Funn som støtter disse betraktningene foreligger nå $\mathrm{i}$ en studie der 33 ungdommer med stor evnemessig spredning ble IQ-testet og MR-undersøkt da de var rundt 14 og 18 år gamle (1).

- Dette er overraskende resultater, men

\title{
Sinktilskudd ved pneumoni hos barn
}

\section{Sinktilskudd kan redusere dødeligheten ved pneumoni hos barn, i hvert fall hos de hivpositive.}

En ugandisk placebokontrollert, randomisert studie (1) av 352 hospitaliserte barn i alderen 6-59 måneder med alvorlig pneumoni, viste relativ risikoreduksjon for død på $67 \%$ 195\% KI 24-85\%) ved tilskudd av sink i tillegg til standard antibiotikabehandling. Mortaliteten var $11,9 \%(21 / 176)$ i placebogruppen og 4,0\% (7/176) i sinkgruppen. Det ble estimert at behandling av 13 barn (number needed to treat) med sink kan hindre ett dødsfall til en kostnad på 4 amerikanske dollar. For det primære endepunktet i studien som var tid til klinisk bedring (definert som normalisering av temperatur, oksygenmetning og respirasjonsfrekvens), var det imidlertid ingen forskjell mellom de to gruppene.

Subgruppeanalyse viste at effekten hovedsakelig skyldtes effekt på hivpositive barn (diagnostisert i samband med studien): Av de 27 barna som fikk placebo døde sju $(25,9 \%)$, mens ingen av de 28 barna som fikk sink døde. Blant de hivnegative barna var det ingen statistisk signifikant forskjell: $5,5 \%$ (7/127) dødelighet i placebogruppen og 3,9\% i sinkgruppen (RR 0,7; $95 \% \mathrm{KI} \mathrm{0,2-2,2).}$ analysene er basert på data fra få personer, sier Kristine Walhovd, professor ved Psykologisk institutt, Universitetet i Oslo. - Studien er derfor ikke spesielt godt egnet til å si noe om hvor stabilt generelt evnenivå er. Det er svært interessant at forskerne fant samvariasjon med endringer i hjernen i tenårene.

Betydningen av disse funnene vil avhenge av om de kan repliseres i et større utvalg personer. Det pågår for tiden flere store studier der barn og unge følges over tid med MRskanning og kognitive tester, og som er velegnet til å belyse spørsmål om hjernens plastisitet. Vi kan altså regne med å få mer kunnskap om dette i nær fremtid, sier Walhovd.

\section{Haakon B. Benestad \\ h.b.benestad@medisin.uio.no}

Universitetet i Oslo

\section{Litteratur}

1. Ramsden S, Richardson FM, Josse $G$ et al. Verbal and non-verbal intelligence changes in the teenage brain. Nature 2011; 479: 113-6.

\section{Glutamat fra gliomer induserer epilepsi}

\author{
Musestudier tyder på at gliomer \\ slipper ut glutamat, som forår- \\ saker kramper.
}

Mange pasienter med hjernesvulster utvikler plagsom epilepsi. Mekanismen har vært lite kjent. Omtrent en tredel av pasientene med gliom utvikler residiverende epileptiske anfall, og glutamat har vært implisert i flere krampetilstander.

En amerikansk forskergruppe har undersøkt glutamats rolle i krampeutvikling hos mus (1). De implanterte gliomceller i immunkompromitterte mus. Musene utviklet epileptogene kramper, og hjernene til musene ble deretter undersøkt. Glutamatnivåene var signifikant forhøyet rundt svulsten, der epileptisk aktivitet oppsto. Ved å hemme utslippet av glutamat medikamentelt ble krampetendensen redusert.

- Resultatene bekrefter at epilepsi ved gliom i stor grad skyldes egenskaper ved svulstcellene og ikke kun lokalisasjon og endret anatomi i svulstområdet, sier Anette Storstein, overlege og forsker ved Nevrologisk avdeling, Haukeland universitetssykehus. - Glutamat er kjent for å senke krampeterskelen, men denne studien viser at epileptisk aktivitet $i$ og rundt et gliom medieres via andre signalveier i glutamatsystemet enn det som er vanlig ved epilepsi. Dette styrker teorien om at gliomepilepsi er en egen sykdomsentitet.

Sulfasalazin, som brukes i behandling av inflammatorisk tarmsykdom, dempet den epileptiske aktiviteten hos forsøksdyrene ved å blokkere den aktuelle glutamatsignalveien. Dette kan ha terapeutisk konsekvens. Hvilken rolle glutamat kan ha for tumorvekst, diskuteres ikke, men andre studier har vist at glutamatfrigjøring kan fremme gliomcellenes vekstegenskaper. Glutamatsignalveiene kan være et felles mål for både epilepsibehandling og tumorrettet behandling ved gliom, sier Storstein.

\section{Kristoffer Brodwall}

\section{kristoffer.brodwall@gmail.com}

Avdeling for internasjonalt samarbeid

Haukeland universitetssykehus
Litteratur
1. Srinivasan MG, Ndeezi G, Mboijana CK et al. Zinc adjunct therapy reduces case fatality in severe childhood pneumonia: a randomized double blind placebo-controlled trial. BMC Med 2012; 10: 14.
2. Haider BA, Lassi ZS, Ahmed A et al. Zinc supple- mentation as an adjunct to antibiotics in the treat- ment of pneumonia in children 2 to 59 months of age. Cochrane Database Syst Rev 2011; nr. 10: CD007368.

\section{Åslaug Helland \\ aslaug.helland@gmail.com Tidsskriftet}

\footnotetext{
Litteratur

1. Buckingham SC, Campbell SL, Haas BR et al. Glutamate release by primary brain tumors induces epileptic activity. Nat Med 2011; 17: 1269-74.
} 